\title{
Identification of hBD-3 in respiratory tract and serum: the increase in pneumonia
}

\author{
H. Ishimoto*, H. Mukae*, Y. Date" ${ }^{\text {, T. Shimbara }}{ }^{\#}$, M.S. Mondal ${ }^{\#}$, J. Ashitani" \\ T. Hiratsuka ", S. Kubo ${ }^{+}$, S. Kohno* and M. Nakazato\#
}

ABSTRACT: Human $\beta$-defensin (hBD)-3, a 45 amino acid antimicrobial peptide, was originally isolated from human skin. hBD-3 mRNA has also been detected in the airways by RT-PCR. While hBD-3 may be involved in antimicrobial defences within the respiratory tract, the presence of hBD3 peptide in the respiratory system has not yet been confirmed.

The antimicrobial activity of the synthesised hBD-3 peptide was measured by a radial diffusion assay and a colony count assay. The present authors confirmed the presence of hBD-3 peptide in homogenates of human lung and serum using reverse-phase HPLC coupled with a highly sensitive RIA. The localisation of the hBD-3 peptide was investigated by immunohistochemistry. In addition, the serum concentrations of hBD-3 were measured by RIA.

hBD-3 exhibited a strong antimicrobial activity, which was unaffected by increasing salt concentrations. Immunohistochemically, the current authors observed the expression of hBD-3 in bronchial and bronchiolar epithelial cells. The mean \pm SD serum concentration of hBD-3 in patients with bacterial pneumonia was $239.4 \pm 17.8 \mathrm{pg} \cdot \mathrm{mL}^{-1}$ in the acute phase and, decreased to $159.3 \pm 20.1 \mathrm{pg} \cdot \mathrm{mL}^{-1}$ after the completion of therapy.

In conclusion, these findings will help elucidate the role of human $\beta$-defensin- 3 in host immune responses and identify the pathophysiological significance of this molecule in respiratory infections.

KEYWORDS: Defensin, immunohistochemistry, pneumonia, radioimmunoassay, respiratory tract

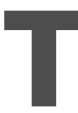
o protect against infections, the respiratory tract possesses a variety of defence mechanisms, including coughing, mucociliary clearance and epithelial cell secretions. The airway surface fluid, which contains bactericidal molecules, such as lysozyme, lactoferrin, secretory phospholipase- $\mathrm{A}_{2}$ and defensins, also exhibits antimicrobial activity.

Defensins, which are strongly cationic, singlechain peptides with molecular masses ranging from 3.5-5 kDa [1, 2], exhibit a broad spectrum of microbicidal activity against gram-positive and gram-negative bacteria, mycobacteria, fungi and certain enveloped viruses [1-3]. Defensins are classified into the $\alpha$ - and $\beta$-defensin subfamilies based on the pairing of cysteines in three disulphide bridges [1]. Six $\alpha$-defensins and four $\beta$-defensins have been previously identified in humans [1]. Human neutrophil peptides (HNPs) 1-4 (HNP-1 to HNP-4), localised to the azurophilic granules of neutrophils, are secreted in the early stages of inflammation, as an antimicrobial agent during systemic infectious disease [4, 5]. The two other remaining $\alpha$-defensins, human defensins 5 and 6 , are made primarily by
Paneth's cells of the small intestine and epithelial cells of the female urogenital tract [1]. Human $\beta$ defensin (hBD)-1 is constitutively expressed in the epithelia of the urogenital and respiratory tracts [6], while hBD-2 is present in the skin, respiratory tissues and gastrointestinal tract $[7$, 8]. A novel hBD, hBD-4, was recently discovered by genomic sequence analysis mapping to chromosome 8p23, the locus containing a cluster of all known $\alpha$ - and $\beta$-defensins [9]. Use of a whole Escherichia coli affinity column capable of binding cationic antimicrobial peptides isolated hBD-3 from lesional psoriatic scales from patients with psoriasis [2]. Using RT-PCR, hBD-3 mRNA expression was detected in the airway, skin and reproductive organs $[2,3]$. While hBD-3 may be involved in antimicrobial defences within the respiratory tract, the presence of hBD-3 peptide in the respiratory system has not yet been observed. In the present study, the authors have confirmed the expression of hBD-3 peptide in human lung. Moreover, concentrations of hBD-3 were determined in serum from patients with bacterial pneumonia and these were compared with those of HNP-1, hBD-1 and hBD-2.
AFFILIATIONS

*Second Dept of Internal Medicine, Nagasaki University School of Medicine, Nagasaki,

\#Third Dept of Internal Medicine,

Miyazaki Medical College, University of Miyazaki,

'National Sanatorium

Miyazakihigashi Hospital, Miyazaki, and

+Peptide Institute, Inc., Osaka, Japan.

CORRESPONDENCE

M. Nakazato

Third Dept of Internal Medicine

Miyazaki Medical College

University of Miyazaki

Kiyotake

Miyazaki 889-1692

Japan

Fax: 81985857902

E-mail: nakazato@med.miyazaki-

u.ac.jp

Received:

September 102004

Accepted after revision:

October 032005

SUPPORT STATEMENT

The present study was supported in part by the 21st Century Center of Excellence Programme and grantsin-aid from the Ministry of Education, Culture, Sports, Science and Technology of Japan. 


\section{MATERIALS AND METHODS \\ Peptide synthesis}

A protected peptide of the hBD-3 peptide was assembled from six segments and a carboxyl-terminal $N^{\mathrm{e}}$-2-chlorobenzyloxycarbonyl-L-lysine benzyl ester monotosylate using $t$-butyloxycarbonyl/benzyl chemistry. Each protected segment, corresponding to amino acids 1-8, 9-15, 16-25, 26-31, 32-37 and 38-44, was elongated on resin using N-(9-(hydroxymethyl)-2-fluorenyl)succinamic acid as a linker as described [10]. The fully protected peptide was subjected to hydrogen fluoride reduction in the presence of $p$-cresol. The resulting reduced peptide was purified by reverse-phase (RP)-HPLC. Oxidative folding reaction was performed for $48 \mathrm{~h}$ at $4{ }^{\circ} \mathrm{C}$ in $2 \mathrm{M}$ ammonium acetate buffer ( $\mathrm{pH} 7.8)$ in the presence of reduced (GSH) and oxidised (GSSG) glutathione at a final ratio of 1:100:10 (reduced hBD-3:GSH:GSSG). A distinct peak eluted at a shorter retention time than that of the fully reduced peptide by RP-HPLC analysis (Zorbax 300SB-C18; Zorbax, Agilent, Palo Alto, CA, USA; at $70^{\circ} \mathrm{C}$ ). This peak was isolated from the reaction mixture by RP-HPLC on an YMC C18 column (YMC, Kyoto, Japan). The crude peptide obtained from this procedure was further purified by RP-HPLC and ionexchange chromatography (IEX) on CM-Sepharose (Sephadex LH-20; Pharmacia Biotech, Uppsala, Sweden). To obtain the acetate form, the purified peptide was passed through a Muromac column (Muromachi Technos Co. Ltd, Tokyo, Japan) and then a Sephadex LH-20 column (the yield of the oxidised peptide is $55 \%$ of that of the reduced peptide). The purity of the resulting synthetic hBD-3 preparation was confirmed by RP-HPLC, IEX-HPLC, capillary zone electrophoresis, amino acid analysis and matrix-assisted laser desorption/ionization time of flight (MALDI-TOF) mass spectrometry (observed $\mathrm{m} / \mathrm{z}$ was 5156.4). The disulfide connectivity of synthetic hBD-3 was determined to be cysteine (Cys)11-Cys40, Cys18-Cys33 and Cys23-Cys41 by enzymatic digestion with a mixture of trypsin and chymotrypsin at $\mathrm{pH} 7.8$, followed by molecular weight and sequence analyses as described [10]. The full length hBD-2 peptide was synthesised by the solid phase technique as previously described [11].

\section{Bactericidal assay}

Radial diffusion [12] and colony count [13] assays were used to examine antimicrobial activity. The present authors tested synthetic hBD-2 and hBD-3 antimicrobial activity by radial diffusion assay using E. coli strain HB101 (Toyobo Co. Ltd, Osaka, Japan). Briefly, bacteria were cultured overnight at $37^{\circ} \mathrm{C}$ in trypticase soy broth (TSB; Nissui Pharmaceutical Co. Ltd, Tokyo, Japan). An aliquot of this culture was transferred to the fresh TSB and incubated for $4 \mathrm{~h}$ at $37^{\circ} \mathrm{C}$ to obtain cells in logarithmic-phase growth. Following the precipitation of bacteria by centrifugation at $800 \times g$ for $10 \mathrm{~min}$, samples were washed in PBS and quantified spectrophotometrically by measuring optical density at $620 \mathrm{~nm}$. A culture volume containing $1 \times 10^{6}$ bacterial colony-forming units (cfu) was then added to $10 \mathrm{~mL}$ warm $\left(40-50^{\circ} \mathrm{C}\right)$ autoclaved PBS containing $3 \mathrm{~g}$ of TSB medium and 1\% low electroendosmosis type agarose. After rapid dispersion of bacteria, the bacteriacontaining agar was poured into plates to form a uniform layer. Wells measuring $3 \mathrm{~mm}$ in diameter were then created in the agar using a gel punch. Diluted peptides or $5 \mu \mathrm{L}$ control samples were added to each well; samples were then incubated for $18-24 \mathrm{~h}$ at $37^{\circ} \mathrm{C}$. Antimicrobial activity corresponds to difference in size between the clear zone surrounding the wells containing defensins and those containing control samples.

The bactericidal activities of hBD-2 and hBD-3 were also examined by colony count assay using Staphylococcus aureus (MRSA; NUMR 101, which was isolated from clinical samples at Nagasaki University Hospital (Nagasaki, Japan) [14]), E. coli HB101 and Pseudomonas aeruginosa PAO1 (supplied by T. Hayashi, Dept of Microbiology, Miyazaki University, Miyazaki, Japan). Bacteria (S. aureus: $1 \times 10^{7} \mathrm{cfu} \cdot \mathrm{mL}^{-1}$; E. coli and $P$. aeruginosa: $5 \times 10^{5} \mathrm{cfu} \cdot \mathrm{mL}^{-1}$ ) were incubated for $2 \mathrm{~h}$ at $37^{\circ} \mathrm{C}$ in $50 \mu \mathrm{L}$ incubation media containing varying concentrations of hBD-2 or hBD-3. Two incubation media conditions were tested: 1) low salt conditions $\left(\mathrm{Na}^{+} 95 \mathrm{mEq} \cdot \mathrm{L}^{-1}, \mathrm{Cl}^{-} 90\right.$ $\mathrm{mEq} \cdot \mathrm{L}^{-1}, \mathrm{~K}^{+} 25 \mathrm{mEq} \cdot \mathrm{L}^{-1}$, osmolarity $210 \mathrm{mOsm} \cdot \mathrm{kg}^{-1}$; $\left.\mathrm{pH} 7.1\right)$ and 2) high salt conditions $\left(\mathrm{Na}^{+} 137 \mathrm{mEq} \cdot \mathrm{L}^{-1}, \mathrm{Cl}^{-} 130 \mathrm{mEq} \cdot \mathrm{L}^{-1}\right.$, $\mathrm{K}^{+} 4.2 \mathrm{mEq} \cdot \mathrm{L}^{-1}$, osmolarity $270 \mathrm{mOsm} \cdot \mathrm{kg}^{-1} ; \mathrm{pH}$ 7.4). The incubation mixtures were serially diluted, spread on nutrient agar plates and incubated for $18 \mathrm{~h}$ at $37^{\circ} \mathrm{C}$. The bactericidal activity is expressed as the colony reduction ratio, defined as the ratio of killed bacteria to control bacteria. All assays were performed in three independent tests with duplicates. The statistical significance of the assay was evaluated using a twotailed t-test; p-values $<0.05$ were considered significant.

\section{Preparation of antiserum}

hBD-3 (2.5 mg) was conjugated to bovine thyroglobulin (15 mg) using 1-ethyl-3-(3-dimethylaminopropyl)carbodiimide hydrochloric acid (400 mg) as described [15]. Samples were then dialysed against $2 \mathrm{~L}$ of $0.9 \%$ sodium chloride five times to remove unconjugated material. The antigenic conjugate solution $(0.7-2.3 \mathrm{~mL})$ was used to immunise three New Zealand white rabbits by multiple intra- and subcutaneous injections. After administering booster shots every 2 weeks, the animals were bled 7 days after each injection. The study and all the experimental protocols were approved by the Ethics Review Committee for Animal Experimentation of Miyazaki Medical College (Miyazaki, Japan).

\section{Study population}

For experiments of western blotting, immunohistochemistry and chromatographic characterisation, the current authors obtained human normal lung tissues from three patients at surgery, including: 1) a male aged 61 yrs with lung cancer; 2 ) a male aged 74 yrs with lung cancer; and 3) a female aged 38 yrs with pulmonary mucormycosis. The patient with pulmonary mucormycosis also exhibited insulin-dependent diabetes mellitus, while the other two patents had no complications that could induce an immunosuppressive condition. All subjects smoked.

For RIA experiments, 20 healthy volunteers (10 male, 10 female) and 20 patients (17 male, three female) with bacterial pneumonia who visited the National Sanatorium Miyazakihigashi Hospital (Miyazaki, Japan) were enrolled in the present study. Healthy volunteers (mean \pm SE age $38.5 \pm 7.7 \mathrm{yrs}$ ) were typically younger than the patients with pneumonia (age $70.0 \pm 17.2 \mathrm{yrs}$ ). Serum was obtained from patients in the acute phase of infection (before treatment with antibiotics). A total of 12 out of 20 patients also provided serum 
samples after completing antibiotic therapy. In the present study, the author's defined completion of therapy as the time point of recovery, patient's examinations revealed normal temperature, no respiratory symptoms and normalisation of the data of C-reactive protein levels. The diagnosis of pneumonia was based on clinical, laboratory (including microbiological) and radiological data in accordance with the guidelines from the Infectious Disease Society of America [16]. Bacterial pneumonia was confirmed by Gram's staining tests and quantitative sputum cultures when possible. The current authors could detect the pathogens in only six out of 20 patients by cultures, with those six patients testing positive for Streptococcus pneumoniae (three), Haemophilus influenza (one), S. aureus (one), and E. coli (one). Although the causative pathogens of the remaining 14 patients were not identified, the patients recovered following empirical therapy with $\beta$-lactam antibiotics, prompting their inclusion in this study. All healthy individuals and patients gave written informed consent.

\section{Immunohistochemistry}

Human lung tissues, isolated as described above, were fixed in $3.7 \%$ formaldehyde in $10 \mathrm{mM}$ PBS ( $\mathrm{pH} 7.2$ ), dehydrated in a graded ethanol series and embedded in paraffin. Cut sections (3- $\mu \mathrm{m}$ thick) were deparaffinised in xylene, rehydrated in graded ethanol series and then washed in Tris-buffered saline (TBS) containing Tween 20 (DakoCytomation Co. Ltd, Kyoto, Japan). For antigen retrieval, the sections were incubated in $1 \mu \mathrm{g} \cdot \mathrm{mL}^{-1}$ proteinase $\mathrm{K}$ (DakoCytomation) for $30 \mathrm{~min}$ at $37^{\circ} \mathrm{C}$, and treated with $6 \%$ hydrogen peroxidase for $60 \mathrm{~min}$ to inactivate endogeneous peroxidases. Nonspecific binding was inhibited by incubation in a protein block (DakoCytomation) for $3 \mathrm{~h}$ at $37^{\circ} \mathrm{C}$. Preparations were incubated overnight at $4{ }^{\circ} \mathrm{C}$ with anti-hBD-3 antiserum at final concentration of $1: 50,000$. Staining was visualised using the Dako CSA system (DakoCytomation) according to the manufacturer's protocol. Control studies utilised normal rabbit serum or anti-hBD-3 antiserum that had been pre-absorbed with $100 \mathrm{pg} \cdot \mathrm{mL}^{-1} \mathrm{hBD}-3$.

\section{Western blot analysis}

Human lung tissues, isolated as described above, were heated at $95-100^{\circ} \mathrm{C}$ for $10 \mathrm{~min}$ in a 10 -fold volume of water to inactivate intrinsic proteinases. After cooling to $4{ }^{\circ} \mathrm{C}$, acetic acid $\left(\mathrm{CH}_{3} \mathrm{COOH}\right)$ and hydrochloric acid were added at final concentrations of $1 \mathrm{M}$ and $20 \mathrm{mM}$, respectively. Following homogenisation in a polytron for $15 \mathrm{~min}$, the homogenate was centrifuged at $18,500 \times g$ for $30 \mathrm{~min}$ at $4^{\circ} \mathrm{C}$. The resulting supernatant was applied to a Sep-Pak C-18 cartridge (Waters, Milford, MA, USA) pre-equilibrated in $0.5 \mathrm{M} \mathrm{CH} \mathrm{CHOH}_{3} \mathrm{CO}$ Peptides were eluted in $50 \%$ acetonitrile $\left(\mathrm{CH}_{3} \mathrm{CN}\right)$ containing $0.1 \%$ trifluoroacetic acid (TFA). The eluate was separated using $12 \%$ reducing sodium dodecyl sulphate-polyacrylamide gel electrophoresis and transferred to polyvinylidene difluoride membranes (Amersham Pharmacia Biotech, Piscataway, NJ, USA) in $20 \%$ methanol, $25 \mathrm{mM}$ Tris-hydrochloric acid, and $0.2 \mathrm{M}$ glycine. Nonspecific binding was blocked by incubating the membranes with $3 \%$ skimmed milk in TBS with $0.1 \%$ Tween 20 for $2 \mathrm{~h}$ at room temperature. Immunoreactive proteins were detected by incubating the membranes with rabbit anti-hBD-3 antibody (1:2,000, respectively) overnight at
$4{ }^{\circ} \mathrm{C}$. Between each step, the membranes were washed three times for $10 \mathrm{~min}$ with TBS/0.1\% Tween 20. Subsequently, the membranes were incubated for $1 \mathrm{~h}$ with anti-rabbit Immunoglobulin (Ig)G conjugated to horseradish peroxidase $(1: 3,000)$, rewashed, and developed using $\mathrm{ECL}^{\mathrm{TM}}$ reagents (Amersham Pharmacia Biotech) and exposed to film.

\section{Radioimmunoassay procedure}

hBD-3 was radioiodinated by the lactoperoxidase method [17]. The ${ }^{125}$ I-labelled peptide was purified by RP-HPLC on a TSK ODS 120A column (Tosoh Co. Ltd, Tokyo, Japan). RIA reaction mixtures were incubated in $150 \mathrm{mM}$ sodium phosphate ( $\mathrm{pH} 7.0$ ) containing $0.25 \% \quad N$-ethylmaleimide-treated bovine serum albumin, $100 \mathrm{mM} \mathrm{NaCl}, 25 \mathrm{mM}$ EDTA.2Na, $0.05 \%$ $\mathrm{NaN}_{3}, 0.1 \%$ Triton $\mathrm{X}-100$ and $3.1 \%$ Dextran T-40. Diluted samples or standard peptide solutions $(100 \mu \mathrm{L})$ were incubated for $24 \mathrm{~h}$ in $100 \mu \mathrm{L}$ of diluted antiserum number 2-7 (final concentration: $1: 1,000,000)$. A solution of the tracer, 16,00018,000 counts per min (cpm) of ${ }^{125}$ I-labelled peptide in $100 \mu \mathrm{L}$ reaction buffer, was incubated with samples for $24 \mathrm{~h}$. Normal rabbit serum and anti-rabbit IgG goat serum were then added for an additional $12 \mathrm{~h}$ incubation. Bound and free ligands were separated by centrifugation. All procedures were performed at $4^{\circ} \mathrm{C}$. Samples were assayed in duplicate.

\section{Chromatographic characterisation of immunoreactive $h B D$ - 3 in lung and serum \\ Lung}

Human lung tissue, isolated and prepared as described above for western blotting, was examined by RP-HPLC on a TSK ODS SIL 120A (Tosoh Co. Ltd) column using a linear gradient of $10-50 \% \quad \mathrm{CH}_{3} \mathrm{CN}$ containing $0.1 \% \quad \mathrm{TFA}$ at a rate of $1.0 \mathrm{~mL} \cdot \mathrm{min}^{-1}$ for $40 \mathrm{~min}$. All fractions were assayed for hBD3 by RIA.

\section{Serum}

Normal human serum $(8 \mathrm{~mL})$ diluted two-fold with $0.9 \%$ saline was applied to a Sep-Pak C-18 cartridge pre-equilibrated with $0.9 \%$ saline. Adsorbed peptides were eluted in $50 \%$

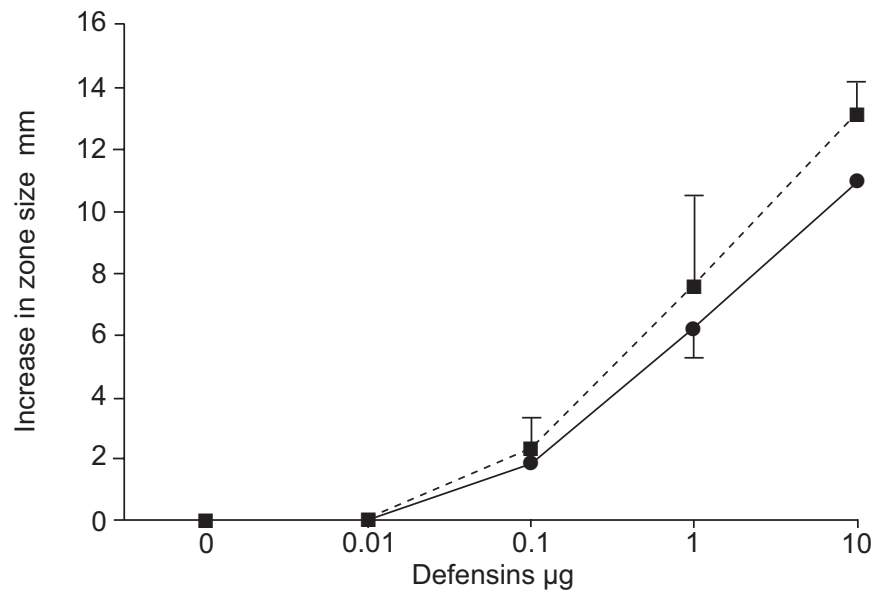

FIGURE 1. Bactericidal activities of human $\beta$-defensin (hBD)-2 (ש) and hBD-3 (-) against Escherichia coli strain HB101. Quantitated increases in zone size represent measurement of the zone size at each defensin concentration minus the zone size of the central control well $(3 \mathrm{~mm})$. Data are presented as the mean $\pm \mathrm{SE}$. 
$\mathrm{CH}_{3} \mathrm{CN}$ solution containing $0.1 \%$ TFA. The eluate was fractionated by RP-HPLC; all obtained fractions were assayed by RIA.

\section{Quantification of serum concentrations of hBD-3 in normal subjects and patients with pneumonia}

Serum samples $(1 \mathrm{~mL})$ were applied to a Sep-Pak C-18 cartridge pre-equilibrated with $0.9 \%$ saline. Adsorbed peptides were eluted in $50 \% \mathrm{CH}_{3} \mathrm{CN}$ containing $0.1 \%$ TFA. Lyophilised eluates were assayed by $\mathrm{hBD}$-3-specific RIA. The serum concentrations of HNP-1, hBD-1 and hBD-2 were also assayed by previously established RIA methods [8, 18, 19]. Data are expressed as the mean \pm SEM. Differences between groups were examined using the Mann-Whitney U-test; p-values <0.05 were considered significant.

\section{RESULTS}

\section{Bactericidal activity of $h B D-3$}

The present authors examined the bactericidal activity of synthesised hBD-3 by radial diffusion assay. hBD-3 exhibited a dose-dependent bactericidal activity against $E$. coli, as was seen with hBD-2 (fig. 1). The bactericidal activities of hBD-3 against
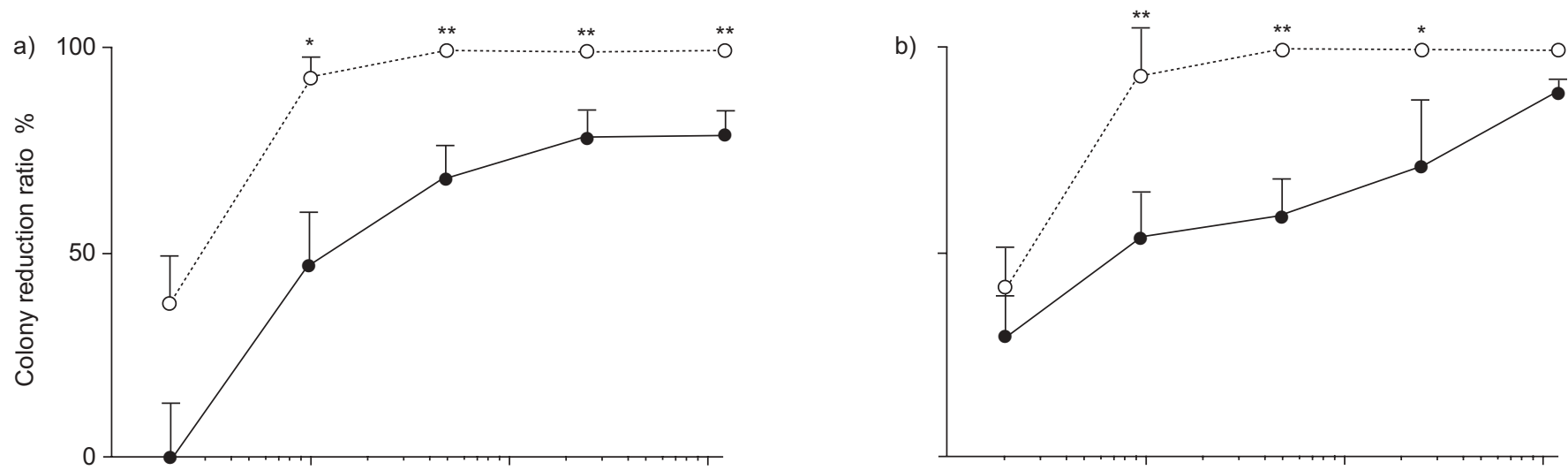

c)
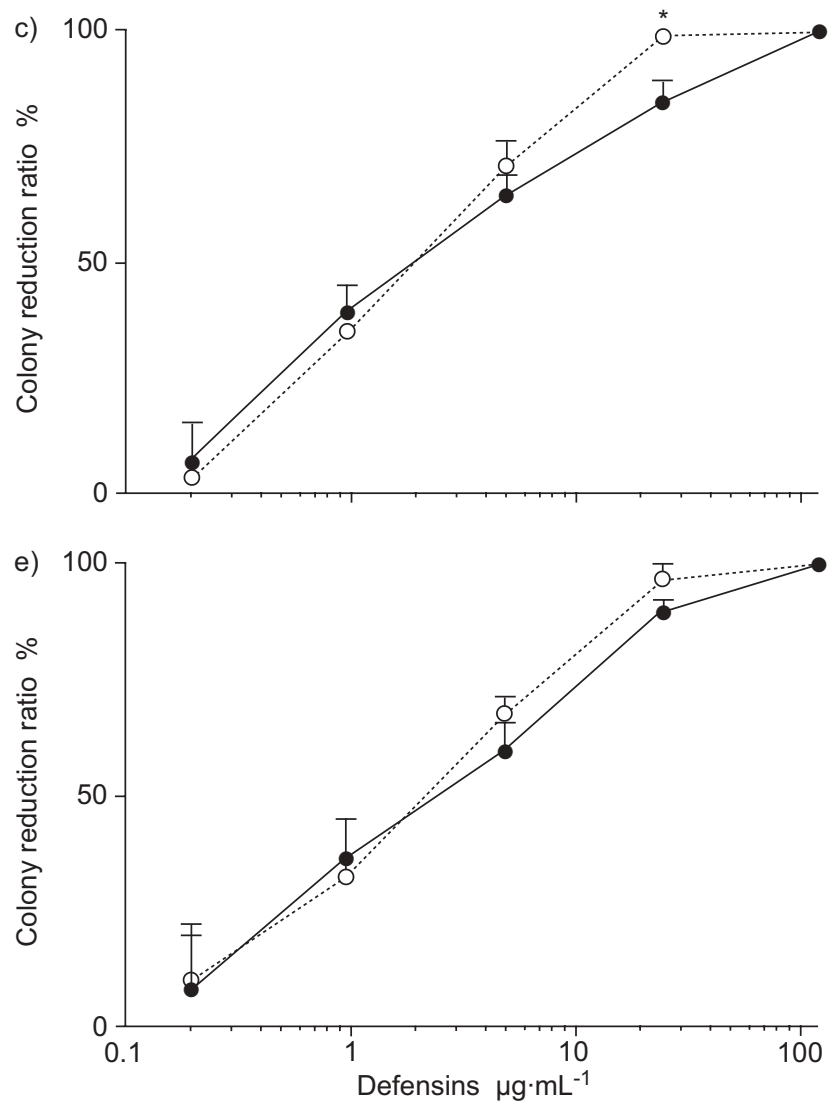

d)

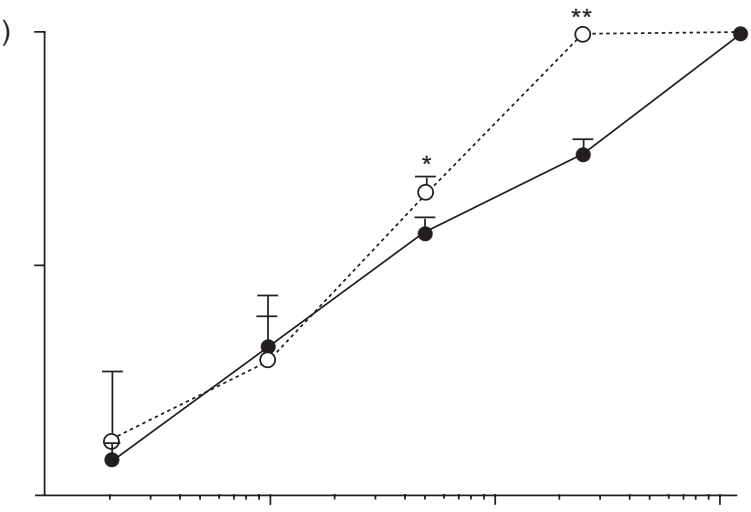

f)

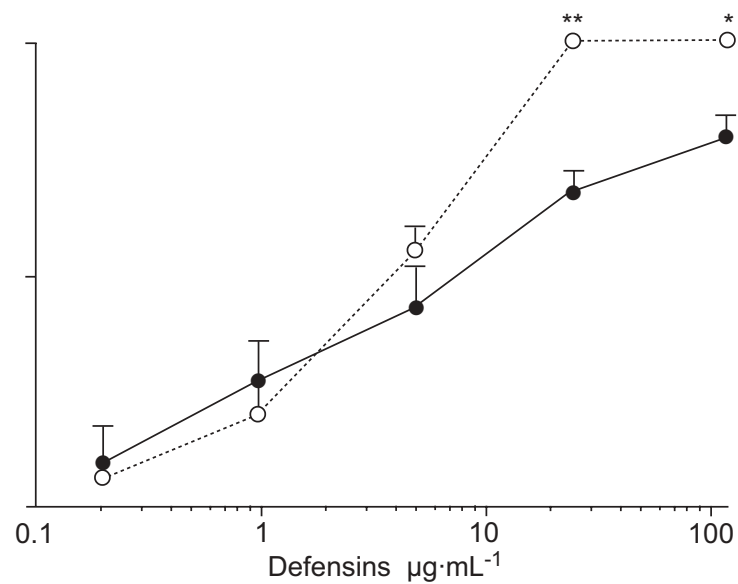

FIGURE 2. Bactericidal activities of human $\beta$-defensin (hBD)-2 $(\bullet)$ and hBD-3 (O) against a) Staphylococcus aureus (MRSA; clinical isolate) in low electrolyte medium, b) S. aureus in high electrolyte medium, c) Escherichia coli HB101 in low electrolyte medium, d) E. coli in high electrolyte medium, e) Pseudomonas aeruginosa PAO1 in low electrolyte medium, and f) $P$. aeruginosa in high electrolyte medium. Bactericidal activity is expressed as the percentage of bacteria killed, obtained from the ratio of surviving bacteria in treated versus control sample. Data are presented as mean \pm SE. *: $p<0.01 ;{ }^{* *}: p<0.001$ versus $h B D-2$. 
S. aureus, E. coli and P. aeruginosa were also investigated by colony count assay using two different electrolyte concentrations (fig. 2). The $90 \%$ inhibitory concentration (IC90) values for hBD-2 against $S$. aureus were $>125 \mu \mathrm{g} \cdot \mathrm{mL}^{-1}$ in low and high salt media, respectively; against $E$. coli were 40 and $60 \mu \mathrm{g} \cdot \mathrm{mL}^{-1}$ in low and high salt media, respectively; against $P$. aeruginosa, the IC90 values were $22 \mu \mathrm{g} \cdot \mathrm{mL}^{-1}$ and $>125 \mu \mathrm{g} \cdot \mathrm{mL}^{-1}$ under low and high salt condition, respectively. For hBD-3, the IC90 against $S$. aureus were 1.0 and $0.9 \mu \mathrm{g} \cdot \mathrm{mL}^{-1}$ in low and high salt media, respectively; against $E$. coli were 13 and $14 \mu \mathrm{g} \cdot \mathrm{mL}^{-1}$ under low and high salt condition; against $P$. aeruginosa, the IC90 were $17 \mu \mathrm{g} \cdot \mathrm{mL}^{-1}$ in both low and high salt media.

\section{Identification of hBD-3 peptide in the lung and serum}

In the three studied lung samples, hBD-3 immunoreactive cells were diffusely observed in the bronchial and bronchiolar epithelium (fig. $3 a$ and b). Airway epithelial cells showed strong and granular cytoplasmatic immunostaining. hBD-3 immunoreactivity could not be detected in either the mucus layers or alveolar epithelial cells. Tissue immunoreactivity was abrogated by pre-absorption of the antiserum with $100 \mathrm{pg} \cdot \mathrm{mL}^{-1} \mathrm{hBD}-3$ peptide (fig. $3 \mathrm{c}$ ).

By RIA, antiserum number 2-7 recognised hBD-3 with a high affinity at final dilutions of 1:1,000,000 (35\% binding).
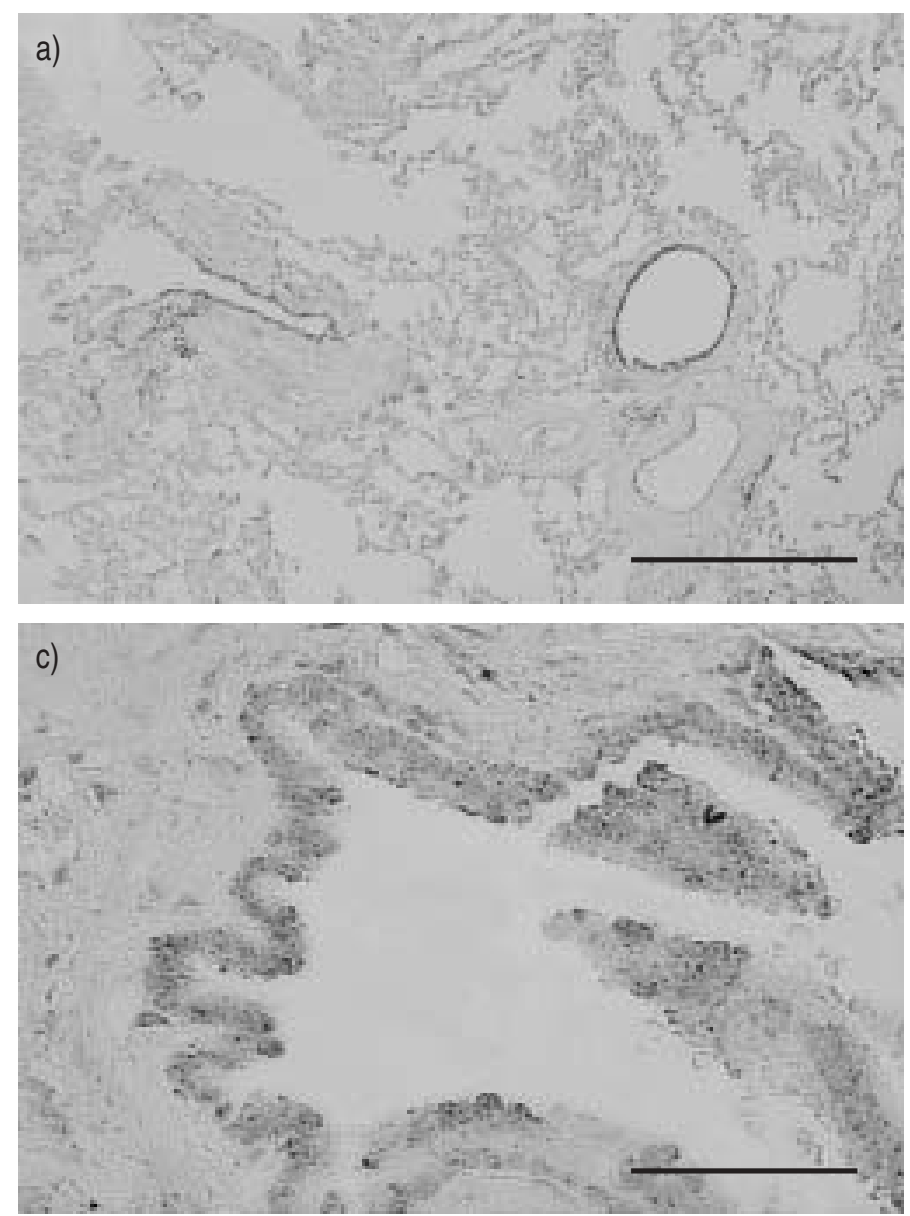

Half-maximal inhibition occurred at $60 \mathrm{pg} \cdot \mathrm{tube}^{-1}$. Peptide remained detectable at the low levels of $6.0 \mathrm{pg} \cdot$ tube $^{-1}$. At $50 \%$ binding, the respective intra- and inter-assay coefficients of variation were 3.6 and $4.6 \%$. This antiserum did not exhibit any cross-reactivity against HNP-1, hBD-1, or hBD-2. Immunoreactive hBD-3 could also be identified in human lung and serum by the combination of RP-HPLC with RIA (fig. 4). In both samples, hBD-3-immunoreactive peaks eluted at the same position as the synthetic hBD-3 peptide. Western blotting experiments also demonstrated the existence of hBD-3 peptide in human lung tissue (fig. 5).

The mean $\pm \mathrm{SE}$ serum concentrations of $\mathrm{hBD}-3$ in normal individuals averaged $142.9 \pm 10.6 \mathrm{pg} \cdot \mathrm{mL}^{-1}$, with no observable differences between the sexes (table 1). The serum concentrations of hBD-3 in 20 patients with an acute phase of bacterial pneumonia were higher than those seen in normal subjects $\left(246.8 \pm 25.4 \mathrm{pg} \cdot \mathrm{mL}^{-1} ; \mathrm{p}<0.01\right)$. The alterations in the serum concentrations of the four defensin family peptides HNP-1, hBD-1, hBD-2 and hBD-3 are detailed in figure 6 for 12 patients with bacterial pneumonia during antimicrobial chemotherapy. While the serum concentrations of HNP-1, hBD-2 and hBD-3 increased during the acute phase of pneumonia, those of hBD-1 did not change throughout the clinical course of the infection.
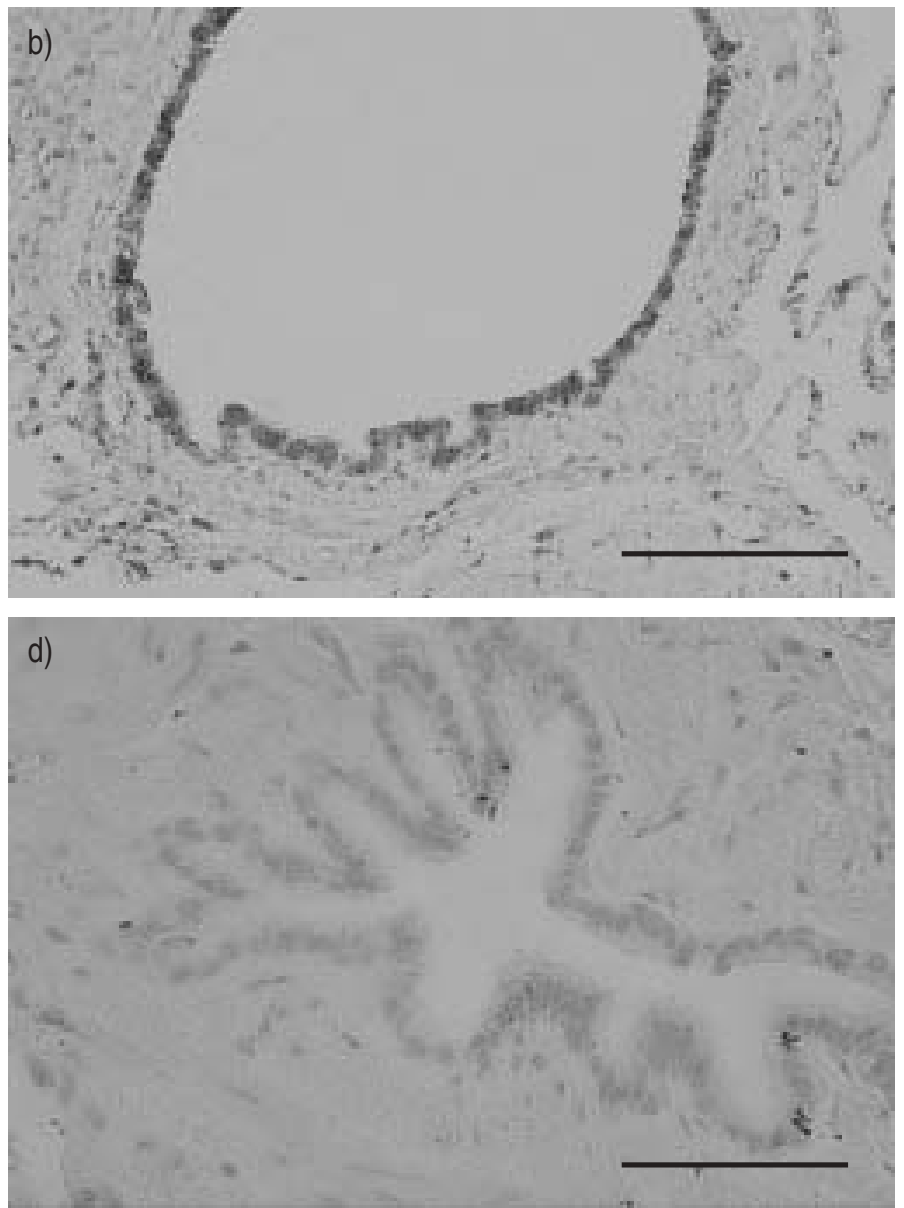

FIGURE 3. a) Bronchiolar epithelial cells stained positively in the immunohistochemical reaction and at higher magnification (b and c). d) No immunoreactivity in tissues when following pre-adsorption of antiserum with $100 \mathrm{pg} \cdot \mathrm{mL}^{-1}$ human $\beta$-defensin-3 peptide. Scale bar=500 $\mu \mathrm{m}(\mathrm{a}), 100 \mu \mathrm{m}$ (b) and $50 \mu \mathrm{m}$ (c, d) 

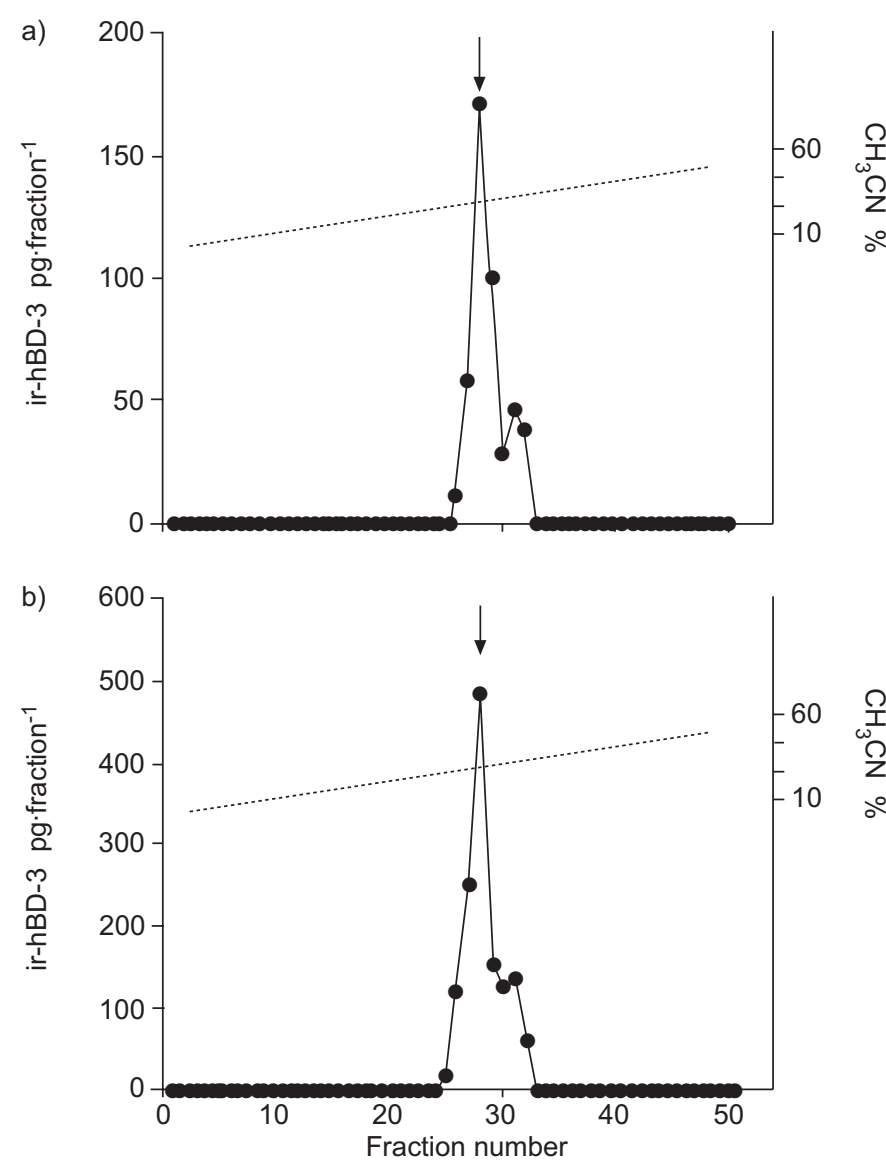

FIGURE 4. Representative reverse phase (RP)-HPLC profiles of human $\beta$ defensin (hBD)-3 immunoreactivity (ir-hBD-3; $\bullet$ ). Samples were obtained from a) $300 \mathrm{mg}$ human lung tissue and b) $8.0 \mathrm{~mL}$ of human serum. Fraction volumes of $0.5 \mathrm{~mL}$ were obtained by RP-HPLC using a TSK ODS SIL 120A (4.6 $\AA \times 150 \mathrm{~mm})$ column and a linear gradient of $10-60 \%$ acetonitrile $\left(\mathrm{CH}_{3} \mathrm{CN}\right.$; ---) containing $0.1 \%$ trifluoroacetic acid at a rate of $1.0 \mathrm{~mL} \cdot \mathrm{min}^{-1}$ for $40 \mathrm{~min}$. Arrows indicate the elution position of synthetic hBD-3.

\section{DISCUSSION}

Defensins comprise a family of genes whose products have complementary functions. However, the systemic distribution and antimicrobial activities of these peptides differ significantly between defensin molecules [1]. hBD-3 is a novel defensin peptide originally isolated from the scales of a patient with psoriasis [2]. While hBD-3 mRNA was detected in human trachea by RT-PCR $[2,3]$, the presence of hBD-3 peptide has not previously been demonstrated in the human respiratory system. Synthetic hBD-3 exhibits a broad-spectrum antimicrobial activity against both gram-positive and gram-negative bacteria [2, 3], while hBD-1 and hBD-2 are more potent against gram-negative bacteria [1, 2]. Recently, host protease cathepsins were shown to degrade defensins; thus, overexpression of cathepsins may produce an environment favouring bacterial infection and colonisation during chronic pulmonary infectious diseases [20]. All defensin molecules are strongly cationic, facilitating their interactions with bacteria and allowing the formation of channels within the negatively charged cytoplasmic membranes [21]. The antimicrobial activities of desalted airway surface fluids (ASF) obtained

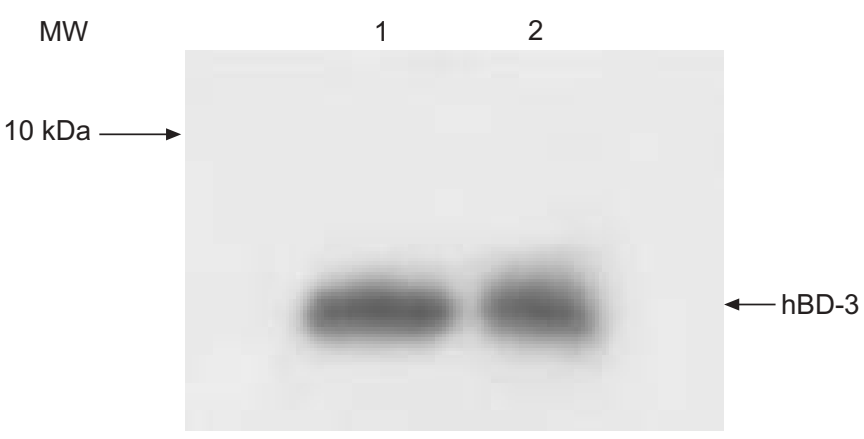

FIGURE 5. Western blotting analysis of human $\beta$-defensin (hBD)-3 peptide expression in human lung tissue. Lane 1: $10 \mathrm{ng}$ recombinant hBD-3 peptide. Lane 2: $10 \mathrm{mg}$ human lung tissue extract (this sample corresponds to the sample in figure 4a). MW: molecular weight.

\begin{tabular}{lll} 
TABLE 1 & $\begin{array}{l}\text { Serum concentrations of human } \beta \text {-defensin-3 in } \\
\text { normal subjects and patients with bacterial } \\
\text { pneumonia }\end{array}$ \\
& $\mathbf{n}$ & $\mathbf{p g} \cdot \mathbf{m L}^{-\mathbf{1}}$ \\
\hline & 20 & $142.9 \pm 10.6$ \\
Normal subjects & 10 & $144.1 \pm 7.1$ \\
Male & 10 & $144.8 \pm 20.4$ \\
Female & 20 & $246.8 \pm 25.4$ \\
Bacterial pneumonia & & \\
\hline &
\end{tabular}

from both cystic fibrosis and normal xenografts were significantly higher than crude ASF obtained from their xenografts [22]. These results suggest that high sodium chloride concentrations may inactivate defensin antimicrobial activity by weakening the electrostatic interactions between defensins and the cytoplasmic membrane. It is plausible that, under these conditions, a greater number of the charged residues in defensins can reduce the salt effect that interferes with the binding of defensins and the negatively charged lipid components of membranes [23]. The present authors ascertained the antimicrobial activities of synthetic hBD-2 and hBD3 under low and high electrolyte conditions. hBD-3 contains more positively charged amino acid residues than other $\beta$ defensins [23], which may account for its similar antimicrobial activity under different sodium concentrations.

The hBD-3 peptide could be detected within the bronchial and bronchiolar regions, but not in the alveolar epithelium. In contrast, hBD-2 is expressed by type- 2 alveolar epithelial cells [24]. This differential distribution of these two defensins may contribute to their unique functions in innate host defences to invading microbes within the respiratory system.

Serum concentrations of hBD-3 in patients with bacterial pneumonia increased during the acute phase, normalising after treatment with antibiotics. Although the mechanism of biosynthesis and release of endogenous hBD-3 peptide are not well understood, the presence of hBD-3 peptide in the 

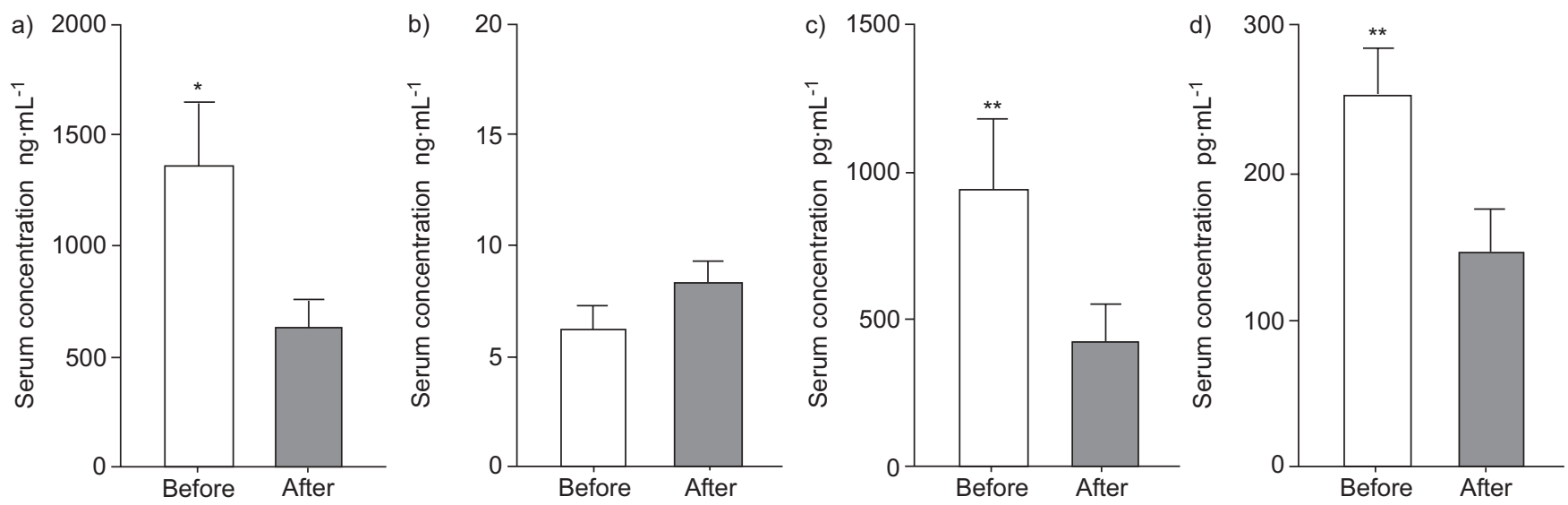

FIGURE 6. The effect of chemotherapy on the serum concentrations of four defensins in 12 patients with bacterial pneumonia: a) human neutrophil peptide-1, b) human $\beta$-defensin (hBD)-1, c) hBD-2 and d) hBD-3. Data are presented as mean \pm SE. *: $p<0.05$; ${ }^{*}$ : $p<0.01$ versus after completion of the therapy.

bronchial and bronchiolar epithelia and the change in serum hBD-3 concentrations during antibiotic therapy for bacterial pneumonia suggest that serum hBD-3 might be secreted by bronchial and bronchiolar cells in bacterial pneumonia.

The current authors previously determined the concentrations of three additional defensins (HNP-1, hBD-1 and hBD-2) in the serum and bronchoalveolar lavage (BAL) fluid during pulmonary disease states [9, 24-29]. The concentrations of both HNP-1 and hBD-2 increased in the serum and BAL fluid during the acute phase of respiratory infections, returning to basal levels after the completion of therapy [25-27]. Serum HNP-1 and hBD-2 concentrations also increased in noninfectious pulmonary diseases, including idiopathic pulmonary fibrosis [27] and diffuse panbronchiolitis [24, 29]. The serum concentrations of hBD-3 also increased in the acute phase of bacterial pneumonia, normalising in the recovery phase. These results suggest that serum hBD-3 concentration mirrors the activity of bacterial pneumonia. hBD-3 gene expression in the respiratory epithelium was also markedly upregulated by interferon- $\gamma$ stimulation and $P$. aeruginosa infection [2, 3], indicating that pathogenic microorganisms and inflammatory cytokines stimulate hBD-3 synthesis and release during respiratory infection.

The presence of human $\beta$-defensin- 3 in the airways, along with its strong bactericidal activity, suggests that human $\beta$-defensin3 functions in humans in innate mucosal defence within the respiratory tract. Establishment of a quantitative assay for human $\beta$-defensin-3 activity will provide a better understanding of the physiological role and pathophysiological significance of this molecule in respiratory infectious diseases.

\section{ACKNOWLEDGEMENTS}

The authors would like to thank T. Minematsu (Nichinan Aisenkai Hospital, Nichinan, Japan) for invaluable advice in the experiments of bactericidal activities. The authors would also like to thank N. Chino (Peptide Institute, Osaka, Japan) for his excellent technical advice in peptide synthesis and, S. Yanagi and S. Tajiri (University of Miyazaki, Miyazaki, Japan) for their excellent technical assistance.

\section{REFERENCES}

1 Bals R. Epithelial antimicrobial peptides in host defense against infection. Respir Res 2000; 1: 141-150.

2 Harder J, Bartels J, Christophers E, Schröder JM. Isolation and characterization of human $\beta$-defensin-3, a novel human inducible peptide antibiotic. J Biol Chem 2001; 276: 5707-5713.

3 García JR, Jaumann F, Schulz S, et al. Identification of a novel, multifunctional $\beta$-defensin (human $\beta$-defensin 3 ) with specific antimicrobial activity. Its interaction with plasma membranes of Xenopus oocytes and the induction of macrophage chemoattraction. Cell Tissue Res 2001; 306: 257-264.

4 Ganz T, Selsted ME, Szklarek D, et al. Defensins, natural peptide antibiotics of human neutrophils. J Clin Invest 1985; 76: 1427-1435.

5 Selsted ME, Harwig SSL, Ganz T, Schilling JW, Lehrer RI. Primary structures of three human neutrophil defensins. J Clin Invest 1985; 76: 1436-1439.

6 Zhao C, Wang I, Lehrer RI. Widespread expression of betadefensin hBD-1 in human secretory glands and epithelial cells. FEBS Lett 1996; 396: 319-322.

7 Harder J, Bartels J, Christophers E, Schröder JM. A peptide antibiotic from human skin. Nature 1997; 387: 861.

8 Hiratsuka T, Nakazato M, Date Y, et al. Identification of human $\beta$-defensin-2 in respiratory tract and plasma and its increase in bacterial pneumonia. Biochem Biophys Res Commun 1998; 249: 943-947.

9 García JR, Krause A, Schulz S, et al. Human beta-defensin 4: a novel inducible peptide with a specific salt-sensitive spectrum of antimicrobial activity. FASEB J 2001; 15: 1819-1821.

10 Nishiuchi Y, Nishio H, Inui T, Bódi J, Kimura T. Combined solid-phase and solution approach for the synthesis of large peptides or proteins. J Pept Sci 2000; 6: 84-93.

11 Kubo S, Chino N, Watanabe TX, Kimura T, Sakakibara S. Solution synthesis of mu-conotoxin GIIIB: optimization of the oxidative folding reaction. Pept Res 1993; 6: 66-72.

12 Takemura H, Kaku M, Kohno S, et al. Evaluation of susceptibility of gram-positive and -negative bacteria to 
human defensins by using radial diffusion assay. Antimicrob Agents Chemother 1996; 40: 2280-2284.

13 Harwig SS, Ganz T, Lehrer RI. Neutrophil defensins: purification, characterization, and antimicrobial testing. Methods Enzymol 1994; 236: 160-172.

14 Yanagihara K, Kaneko Y, Sawai T, et al. Efficacy of linezolid against methicillin-resistant or vancomycininsensitive Staphylococcus aureus in a model of hematogenous pulmonary infection. Antimicrob Agents Chemother 2002; 46: 3288-3291.

15 Miyata A, Kangawa K, Toshimori T, Hatoh T, Matsuo H. Molecular forms of atrial natriuretic polypeptides in mammalian tissues and plasma. Biochem Biophys Res Commun 1985; 129: 248-255.

16 Bartlett JG, Breiman RF, Mandell LA, File TM Jr. The guidelines for community-acquired pneumonia in adults from the Infectious Disease Society of America. Clin Infect Dis 1998; 26: 811-838.

17 Miyata A, Mizuno K, Minamino N, Matsuo H. Regional distribution of adrenorphin in rat brain: comparative study with PH-8P. Biochem Biophys Res Commun 1984; 120: 1030-1036.

18 Shiomi K, Nakazato M, Ihi T, Kangawa K, Matsuo H, Matsukura S. Establishment of radioimmunoassay for human neutrophil peptides and their increases in plasma and neutrophil in infection. Biochem Biophys Res Commun 1993; 195: 1336-1344.

19 Hiratsuka T, Nakazato M, Ihi T, et al. Structural analysis of human $\beta$-defensin-1 and its significance in urinary tract infection. Nephron 2000; 85: 34-40.

20 Taggart CC, Greene CM, Smith SG, et al. Inactivation of human beta-defensins 2 and 3 by elastolytic cathepsins. $J$ Immunol 2003; 171: 931-937.
21 Bals R, Wang X, Wu Z, et al. Human $\beta$-defensin 2 is a saltsensitive peptide antibiotic expressed in human lung. $J$ Clin Invest 1998; 102: 874-880.

22 Bals R, Weiner DJ, Meegalla RL, Accurso F, Wilson JM. Salt-independent abnormality of antimicrobial activity in cystic fibrosis airway surface fluid. Am J Respir Cell Mol Biol 2001; 25: 21-25.

$23 \mathrm{Wu} \mathrm{Z}$, Hoover DM, Yang D, et al. Engineering disulfide bridges to dissect antimicrobial and chemotactic activities of human $\beta$-defensin 3. Proc Natl Acad Sci USA 2003; 100: 8880-8885.

24 Hiratsuka $\mathrm{T}$, Mukae $\mathrm{H}$, Iiboshi $\mathrm{H}$, et al. Increased concentrations of human $\beta$-defensins in plasma and bronchoalveolar lavage fluid of patients with diffuse panbronchiolitis. Thorax 2003; 58: 425-430.

25 Ashitani J, Mukae $H$, Hiratsuka $T$, Nakazato $M$, Kumamoto K, Matsukura S. Elevated levels of $\alpha$-defensins in plasma and BAL fluid of patients with active pulmonary tuberculosis. Chest 2002; 121: 519-526.

26 Ashitani J, Mukae H, Hiratsuka T, Nakazato M, Kumamoto K, Matsukura S. Plasma and BAL fluid concentrations of antimicrobial peptides in patients with Mycobacterium avium-intracellulare infection. Chest 2001; 119: 1131-1137.

27 Ihi T, Nakazato M, Mukae H, Matsukura S. Elevated concentrations of human neutrophil peptides in plasma, blood, and body fluids from patients with infections. Clin Infect Dis 1997; 25: 1134-1140.

28 Mukae $\mathrm{H}$, Iiboshi $\mathrm{H}$, Nakazato $\mathrm{N}$, et al. Raised plasma concentrations of $\alpha$-defensins in patients with idiopathic pulmonary fibrosis. Thorax 2002; 57: 623-628.

29 Ashitani J, Mukae H, Nakazato M, et al. Elevated concentrations of defensins in bronchoalveolar lavage fluid in diffuse panbronchiolitis. Eur Respir J 1998; 11: 104-111. 